\title{
Vowel Variation Between American English and British English
}

\author{
Afzal Khan ${ }^{1} \&$ Soleman Awad Mthkal Alzobidy ${ }^{2}$ \\ ${ }^{1}$ Department of English, Alasala University, King Fahad Airport Road, Dammam, Kingdom of Saudi Arabia \\ 2 Department of English Language and Translation, College of Sciences and Theoretical Studies, Saudi \\ Electronic University, Kingdom of Saudi Arabia \\ Correspondence: Afzal Khan, Department of English, Alasala University, King Fahad Airport Road, Dammam, \\ Kingdom of Saudi Arabia. E-mail: afzalenghu@gmail.com
}

Received: April 17, 2018 Accepted: November 13, 2018 Online Published: December 29, 2018

doi:10.5539/ijel.v9n1p350 URL: https://doi.org/10.5539/ijel.v9n1p350

\begin{abstract}
The English Language, being an international language, is spoken all over the world with many variations. These variations occur primarily due to environmental, cultural and social differences. The main reasons for these variations are intermingling of different races and strata in a society. In this regard prominent differences can be observed at phonological levels. These phonological variations produce different kinds of English, like British and American English. In these two there are differences in intonation, stress pattern, and pronunciation. Although South-Eastern British R.P. is known as Standard English but one cannot deny the existence and value of American English. The study attempts to highlight the vowel variation between British English and American English at phonological level.
\end{abstract}

Keywords: vowel, variations, American English, British English, phonological

\section{Introduction}

Phonological variation results due to variations in dialects. A dialect is a system of speech sufficiently different from other dialects to be seen as different, yet sufficiently the same as other dialects to be seen as a similar. English is the Language, which is broadest in nature and possesses many dialects, and each dialect has different social and regional sub-dialects. American English, British English, Australian English, Canadian English and African English. These are the major dialects of English. In this study the researchers concentrate on American English and British English. British English is important because Britain is the cradle of English, and American is significant because of highest number of English speaker live in North America. Although both dialects are variant in many respects, the researcher will focus on phonological vowel variation between both types of English.

This study will further elaborate the differences in stress pattern and the variant use of vowels in British English and American English. It will help in understanding how American and British English stress syllables differ in same word, and how the shift in stress changes the pronunciation; how same vowels are pronounced differently; how vowels like " $a$ ", " $e$ ", " $i$ ", "o" are different in both dialects.

\section{Literature Review}

The geographical extension of English language is so unique among the languages of the world, not only in this age but throughout the history. In the present scenario English is the first language in majority twenty-three countries. It is the official language or joint official language in about fifty other countries, there English is used in to the indigenous first language for a range of public and private functions. The states and countries where English is used as a first or second language are situated in all five continents of the world. The population who use English of these countries amount to around 2.5 billion, almost 49 percent population of the whole world. Where English is used as the first or second language for multiple reasons and functions, it is used inside for communication in these countries. Furthermore, English is used widely as a foreign language for international communication.

The differences between British and American English are known in many levels such as phonology, vocabulary, grammar and semantics (Abderrahim, 2015). There are over 300 million native speakers of English language out of whom 216 million live in the United States, the United Kingdom 53 million, Canada over 17 million, and 
Australia 14 million. This research only focuses on vowels variation between the American English and British English (Depraetere, 1998).

\subsection{British English}

Phonological vowel variation in British English is the result of a number of tribal migration and invasion. About the middle of the $5^{\text {th }}$ century A.D, three German tribes-the Angles, the Saxons and the jutes-began a successful invasion of what is now England. The gradual fusion of their three dialects resulted in old English accent. The second major invasion was that of Vikings, which began as a series of raids about $9^{\text {th }}$ century and also developed into a mass migration. Their language gradually merged with the related Anglo-Saxon dialects, and a great deal of interchange and borrowing of words occurred.

The third major invasion to have a great influence on the language was the Norman Conquest, led by William the conqueror in 1066. The Normans were descendants of Vikings who had earlier settled in Normandy and had adopted the French dialect of their new home as their own. After the conquest the business of the government, or the court, was conducted in Norman French. The French were in control, and French became the language of the nobility, the court, polite society, and literature. English as a written language almost disappeared, but despite the prestige and use of French among the rulers and landlords, French did not replace English as the speech of the common people (Jackson \& Amvela, 2007).

Another but peaceful invasion was that of Latin in 597 A.D, when the Roman missionary Saint Augustine arrived in England and converted the kingdom of Kent to Christianity. Thus began an influence that has continued to enrich English through Latin borrowings.

English developed and changed with the passing of time, as do all living entities in the world. During the long period after the Norman Conquest when English was neglected in favor of French, English became practically a spoken dialect. At this time it was transformed into a new standard speech, casting off much that was superfluous. By the time it emerged again as a literary language, around 1200 century, it had assumed the form known as Middle English. Qiong (2004) states British English tends to be the major variety of English because that is taught in many European educational institutions, for the simple reason that it is more useful (and closer) to them than American English.

Middle English is old English changed first by French influence and second by the transforming power of popular speech. The consequences were profound. From a rather inflected language, English changed to one of few inflections. Along with the simplification of the grammatical structure went an increase in vocabulary and idiom, particularly under the influence of the French language. When we look at English across the world today we will find therefore that it varies enormously in accordance with its wide range of functions, and because it bears the imprints of the languages with which it has made contact (Leith \& Leith, 2005).

As a product of two merging strains, Germanic and Romance-French is a Romance language, descended from Latin-English became a language capable of expressing a wide range of thought and feeling, as exemplified in the work of Chaucer, the greatest literary figure of medieval England. Chaucer wrote in the East Midland dialect, which has risen to a commanding position among forms-Northern, Midland and southern.

East Midland was the dialect of London, the capital and metropolitan center of England, politically, commercially, socially and intellectually prominent. It held a middle course between the more conservative southern dialect and the more advanced Northern, and developed into the speech Chaucer used. It is also a dialect from which standard Modern English is derived (Algeo, 2001).

In the modern English period the people of England followed a generally peaceful line of development in their right in language, as they were not subjected to foreign invasion or any extensive external ethnic influences. The language developed along with the political, industrial, and intellectual growth of the country and of the world as a whole.

\subsubsection{R.P Pronunciation}

The spoken standard as it is sometimes known, the Received Pronunciation (R.P) is something which varies in different parts of the English speaking world. In England it is a type of English perhaps best exemplified in the speech of those educated in the public schools, but spoken also with a fair degree of uniformity by cultivated people in all parts of England. It is a class rather than regional dialect, but it is still very close to the South-East region of England. This is not the same as the spoken standard of the United States, Canada or Australia, a variety of the English as affected or pretentious (Hughes, Trudgill, \& Watt, 2013). 


\subsection{American English}

\subsubsection{The settlement of America}

The English language was initially brought to America by the colonists during seventeenth century who settled down along the Atlantic coast. It was the vernacular of English people spoken in England in those days, it was the language used by Milton and Shakespeare. In the development of language and the people who migrated there and used English of this country three great periods are important of European immigration here. The first spreads from the settlement of the colonists Jamestown that happened in 1607 and remained there till the colonial period. Historically this can be initiated at 1787, when federal constitution was finally approved by the congress, or at 1790, when it was ratified by the last colonies and the first census was conducted. At this time the total number of population was 4,000,000 people, amid this 95 percent people lived east of the Appalachian Mountains; while 90 percent people came from different parts of the British Isles. The second major colonial period consists spread out of thirteen colonies that situated to the west of the Appalachian, started with south and then entered into the old Northwest territories, and finally ended at the Pacific. This epoch can be linked with the emergence of civil war, in 1860, and also known for the fresh arrival of immigrants from two well-known sources i-e Ireland and Germany.

Failure of potato crops caused a large immigration of Irish people in 1845, participated a whole exodus towards America, this decades evidenced a million and a half emigrants. At around the same period the failure of German revolution caused equal number of migration in 1848. The third period, the period since the civil war, is marked by an important change in sources that obliged the colonists to migrate. In the former two periods of colonists' immigration, actually up to 1890 , the British Isles along with the Teutonic countries of Northern Europe supplied 75 to 90 percent people in all who migrated to this country. Even during the final square of the nineteen century witnessed a major chunk consisted of almost a million Scandinavians migrated there, more than one fifth of the total population of Sweden and Norway, mostly settled in the upper Mississippi valley of America. Along with the European races that make up the bulk of the American population, there should be mentioned some fifteen Negroes, mostly settled in the South and in the large cities of North and East (Baugh, 1957).

The first period of immigration is the most important in nature, because they were the primary colonists that brought with them English language and established its phonological form. Those who migrated latter were mostly adjusted in a generation or two, their influence can be felt but difficult to ascertain and define it.

The transporting of English to the American colonies in the $17^{\text {th }}$ and $18^{\text {th }}$ century resulted in isolation of one group of speakers from another. In due course, American English pattern became different in pronunciation from British to be called two verities. By the middle of the $18^{\text {th }}$ century British visitors to America were already commenting on the "Barbaric" quality of the American Language. British playwright George Bernard Shaw once ironically remarked that the United States and Britain were "two countries separated by common language".

Today American English according to language scholars consists of three major verities, differentiated on the basis of Phonological variations, the Northern variety, the Midland and the Southern accent.

\subsubsection{The Northern Accent}

A typical pronunciation feature of the Northern accent is the contrast between the $/ p /$ (as in moan) in horse, fourteen and mourning and the $/ \mathrm{J} /$ (as in taught) in horse, forty and morning. These words are pronounced alike in other dialects.

Another colorful minor dialect of the Northern area is that of "New York City" New Yorkers use a characteristic diphthong /ay/ (pronounced as "uh-ee") in such words as "Prime, tide, and "time" (Levine, 1971).

\subsubsection{The Midland Accent}

The midland accent has more speakers and is perhaps spreading more vigorously than any other. Typical pronunciation features include the use of /æ/ (as in hat) in such words as "afternoon" "bath" and "glass".

An important minor sub vowel phonological variation is found in "South Midland" which has spread from the Southern Mountains to parts of the Mideast, then into the Rocky Mountains States as for as California. South Midland forms are also found in parts of the Southwest, including Texas. A familiar vowel pronunciation feature is the use of $/ a h /$ for the diphthong /ay/ (pronounced "ah-ee") in such words as "time" eyes" right" and nice" (Levine, 1971).

\subsubsection{The Southern Accent}

Southern speakers substitute /i/ for /e/ in all words so that the following pairs of words would pronounce alike: cents, since; pen, pin; ten, tin. 
A well-known minor sub set of pronunciation in the area is "Eastern Virginia" where diphthong /ew/ instead of the more common /aw/is used in such words as "house" "about" and "mouse" (Levine, 1971).

It is generally agreed among linguists that there are at least three kinds of social dialects with distinct vowel variation in the United States today. Although there are no standardized labels for these three types, we can describe them as,

i) Cultivated speech: which is the language of educated upper or middle class persons living mostly in urban and suburban communities, in wealthy communities this may be the only pronunciation regularly used.

ii) Folk speech: which is the accent adopted by uneducated rural folk living in isolated communities. Often, outsiders assume this accent to be the standard for the area, because it is distinctive and colorful, but a closer observation usually reveals other social accents within the same locality.

iii) Common speech: This ranges between the other two and is spoken by the majority of Americans in daily communication.

\section{Methodology}

Method and Sample to verify American English and British, and accordingly its transcription will reveal phonological variation between British and American English and will explore that how the native speakers using two varieties that differ substantially in term of vowels from each other whether they are aware of the variation between the two varieties. The targeted words carry the vowel sounds were written used in a paragraph and the participants were asked to read the passage for three times. Recordings were conducted with native speakers of the two varieties. The experiment used recordings articulated by the participants of the two varieties, for a total of 38 items for each variety of English. Of course, the research has no presumption of generalization, because of the limited sample made up of 50 respondents for each variety. The native speakers were first identified as Americans or British working in different Universities in Saudi Arabia. Appointments were made through personal visits and all respondents were informed about the aims of the research. Demographic questions were also included to gather data relating to the participants' age, sex, occupation, level of education, and for how long they had ever been living in Great Britain or USA.

\subsection{Data Analysis}

The recorded words were listened for a number of times with a good quality speaker and transcribed accordingly to reveal the variations between the two varieties. All respondents ranged from 11 to 60 years of age. The American respondents included 37 women and 13 men, while the British sample was composed of 34 women and 16 men. Both samples were mostly between 30 and 40 years old, as can be seen in the comparative (table 1, $2,3,4)$.

\section{Results}

Table 1. British prefer broad "a" while American flat " $\alpha$ "

\begin{tabular}{|c|c|c|}
\hline Words & British Pronunciation & American Pronunciation \\
\hline Laugh & /læf/ & /lo:f/ \\
\hline Draft & /dræft/ & /dra:ft/ \\
\hline Branch & /brænt $\int /$ & /bra:ntf/ \\
\hline Command & $/ \mathrm{k} \partial^{1}$ mænd/ & $/ \mathrm{k} \partial^{1} \mathrm{~m} \alpha: \mathrm{nd} /$ \\
\hline Chant & $/ \mathrm{t} \int \mathrm{nt} /$ & $/ \mathrm{t} \int \alpha: \mathrm{nt} /$ \\
\hline Ask & /æsk/ & $/ \alpha: \mathrm{sk} /$ \\
\hline Clasp & /klæsp/ & $/ \mathrm{kl} \alpha: \mathrm{sp} /$ \\
\hline Last & /læst/ & $/ 1 \alpha: s t /$ \\
\hline Grass & /græs/ & /gra:s/ \\
\hline Path & $/ \mathrm{p} æ \theta /$ & $/ \mathrm{p} \alpha: \theta /$ \\
\hline Gasp & /gæsp/ & /ga:sp/ \\
\hline Quality & $/{ }^{1} \mathrm{kwpləti} /$ & $/{ }^{1} \mathrm{kw} \alpha:$ ləti/ \\
\hline Parasol & /pærəsb1/ & $/ \mathrm{s} \alpha: 1 /$ \\
\hline
\end{tabular}


Table 2. Vowel variation in "e" between British English and American

\begin{tabular}{|c|c|c|}
\hline Words & British Pronunciation & American Pronunciation \\
\hline Again & /ongein/ & $/ a^{1} \mathrm{gen} /$ \\
\hline Patent & $/{ }^{1}$ peitnt/ & /1 pætnt/ \\
\hline Apparatus & /æpə ${ }^{1}$ reitəs/ & /æpə⿳亠丷⿵冂⿰丨丨/ \\
\hline Radio & /1 reıdiou/ & loo/ \\
\hline Charade & $/ \int \partial^{1} \mathrm{r} \alpha: \mathrm{d} /$ & / $\partial^{1}$ reid/ \\
\hline Promenade & /proməln $\alpha: \mathrm{d} /$ & /pra:mə1ne1d/ \\
\hline Patriotism & /1 pætrip 1 tızəm/ & $/{ }^{1}$ peltrio ${ }^{1}$ tizəm/ \\
\hline Either & $/{ }^{1} \mathrm{a} 182 /$ & /1i:४ə/ \\
\hline Neither & /'naløə/ & /[1ni:ชə/ \\
\hline
\end{tabular}

Table 3. Vowel Variation in "o" between American English and British

\begin{tabular}{|c|c|c|}
\hline Words & British Pronunciation & American Pronunciation \\
\hline Rock & $/{ }^{1} \mathrm{rok} /$ & $/{ }^{1} \mathrm{r} \alpha: \mathrm{k} /$ \\
\hline Autocracy & /o: ${ }^{1}$ tokrəsi/ & $/ 0:{ }^{1} \mathrm{t} \alpha: \mathrm{kr} ə \mathrm{si} /$ \\
\hline
\end{tabular}

Table 4. Vowel Variations in "y" preceding "u” between American English and British

\begin{tabular}{|c|c|c|}
\hline Words & British Pronunciation & American Pronunciation \\
\hline Duty & /'dju:ti/ & $/{ }^{1} \mathrm{du}: \mathrm{ti} /$ \\
\hline Tube & $/$ tju:b/ & $/ \mathrm{tu}: \mathrm{b} /$ \\
\hline News & /nju:z/ & /nu:z/ \\
\hline Nude & /nju:d/ & /nu:d/ \\
\hline Duke & /dju:k/ & /du:k/ \\
\hline Tuesday & /1'ju:zde1/ & $/{ }^{1}$ tu:zdel/ \\
\hline Enthusiasm & $/$ In $^{1} \theta$ ju:zıæzəm/ & $/$ ln $^{1} \theta \mathrm{u}: z 1 æ z ə m /$ \\
\hline Stupid & $/{ }^{1}$ stju:pid/ & /1stu:pıd/ \\
\hline Suit & /sju:t/ & /su:t/ \\
\hline Due & /dju:/ & /dju:/ \\
\hline Tube & /tju:b/ & $/ \mathrm{tu}: \mathrm{b} /$ \\
\hline Duty & $/{ }^{\prime}$ dju:ti/ & $/{ }^{1} \mathrm{du}: \mathrm{ti} /$ \\
\hline Nude & /nju:d/ & /nu:d/ \\
\hline Pure & /pjoə/ & /pjor/ \\
\hline
\end{tabular}

\section{Discussion}

Every vowel sound without exception has a different value in British English and American English. In many cases the change is so great that exact setting down of it an accurate transliteration would involve a totally different spelling. Even the " $\alpha$ " of such words as "cab" and "hand" differs in the two countries. When Englishmen speak them rapidly they often sound, to American ears, like "keb" and "hend".

Many words have short vowels in American instead of the long vowels or diphthongs usual in English. The English authorities ordain the long "e" in evolution, and long "i" in words of the "fragile" class, but in the United States short "e" and "i" seem to be dominant words.

There is also a tendency to substitute the short "e" of "pen" for the long "e" of "scene" in penalize; the short "i" of $\sin$ for the long "i" of "line" in "sinecure"; and the short " $\mathrm{u}$ " of "sum" for the long "u" cube in "quintuplet". In both English and American usage there is a strong movement toward substituting the so-called natural vowel for clearer vowels in unstressed syllables, especially in colloquial speech. Thus the " $\alpha$ " of "about", the "e" of the "the", "i" of "habit", the "o" of "hillock", and the "u" of "upon" are all reduced to a grunt.

One of the most noticeable differences between the average American speech and that of Standard English lies in the varying pronunciation of " $\alpha$ " in about 150 words in everyday use. The English in general prefer the broad " $a$ " of "dark" before $f, f t, n c h, n d, n t, s k$, sp, st, ss, and th, as in laugh, draft, branch, command, chant, ask, clasp, last, grass, and path, Whereas most Americans use the flat " $\alpha$ " not only in bath, gasp, and path, but also in, quality.

In fact the " $\alpha$ " is retained by the English in large number of words-perhaps in quite as many as show the broad " $\alpha$ " that Americans think of as characteristics of England. Examples are fancy, pants, vassal, pantry, lass, car, mandate, pamphlet, ant, ass, parasol, candle, passenger, parrot, handsome and passive (Mencken, 1948-73). 
One debate that engrosses the phonologists has to do with again. Should it be pronounced to rhyme with pain or with pen? In Standard English the former is good English usage but the Americans believe that "agen" is better. Down to the nineteenth century the English poets freely rhymed again with pen, but Shakespeare also rhymed it on occasion with twain, plain, slain. One opinion is that again was than displacing 'agen' in England and this seems to be confirmed by the English authorities but most American authorities hold out for 'agen' (Jones, 2011).

Patent, in American usually has the " $\alpha$ " of Cat, but in English the " $\alpha$ " of late is often heard when the word is used in the sense of a license or monopoly.

In English the third " $\alpha$ " of apparatus is always that of Tate, but in the United States it is often that of cat. In "radio" the usual American pronunciation the " $\alpha$ " of mate, but the plain people of New York city often have that of rack, The English use a broad " $\alpha$ " in the final syllable of charade and promenade, but most American prefer the " $\alpha$ " of mate. In England the " $\alpha$ " of patriotism is always the " $\alpha$ " of rack, but in the United States it is usually that of late.

Regarding the word either and neither, mostly American Pronounce it as ee-ther and nee-ther, whereas the English prefer eye-ther and nye-ther. The English use the long "e" of bee in the first syllable of evolution and epoch, but Americans prefer it short.

The differences between the English "o" in rock and the American "o" in the same word have long engaged phonologists. The English " $o$ " is a lightly rounded vowel, though it is close to the short form of the American " $\alpha w$ ". Heard in the opening syllables of autocracy; In American it sounds like $\alpha h$ sound usually heard in "not". Cultivated English Speakers do not recognize this $\alpha h$ sound in the words commonly spelled on " $o$ " e.g, not, rod, rock, fog, hop, rob, pomp, on, beyond, novel.

Sometimes another sound is heard in "wa" words in American that is " $\alpha w$ ". One encounters it in water, wash, swamp, swan, and squalid, which become, roughly wawter, wawsh, swawmp, swawn and squawlid. It also appears in God, which may be variously God, Gahd, or Gawd in his ordinary discourse will switch to God when he wants to show reverence.

The English are more careful than Americans with the shadowy " $y$ " preceding " $u$ " in the words of the duty, tube, new class. The English pronunciation nyews, nyude, dyuke, tyuesday, enthyuisam, styupid and syuit seem affectation to the Americans. Americans use doo for due, toob for tube, dooty for duty, nood for nude, but one can never find any American who used "oo" after $p, b, m$ or $\mathrm{f}$ to give poor (for pure), booty ( for beauty), moosic or foo (for few) (Webster, 1961).

The main phonological variation between American English and British English are in vowel sounds. Vowel variations are so great in British English and American English that sameness of word cannot be identity. The " $\alpha$ " sounds differently in American English and British English. As "cab" sounds like Keb in British English. English "o" as in "rot" becomes broad " $\alpha$ " as in "ask". English prefer broad " $\alpha$ " as in "laugh", "last", "grass", "command", and "chart"; whereas most American use flat " $\alpha$ " of "that". In American English "again" rhyme with "pen", whereas, in British English it rhymes with "pain". The English are more careful than Americans with shadowy " $y$ " preceding " $u$ " in the words of the "duty" or "tube" class. Americans prefer "tools" "dooty" "nood" rather than British "tube", "duty", "nude".

\section{References}

Abderrahim, S. (2015). British VS American English for university students teaching purposes: the case of third year EFL students at Tlemcen University. Doctoral dissertation.

Baugh, A. C. (1957). A History of the English Language. New York: Appleton-Century-Crofts.

Algeo, J. (Ed.). (2001). The Cambridge history of the English language (Vol. 6). Cambridge University Press.

Jones, D. (2011). Cambridge English pronouncing dictionary. Cambridge University Press.

Depraetere, I. (1998). Sidney Greenbaum. The Oxford English Grammar. Functions of Language, 5(2), 257-264.

Hughes, A., Trudgill, P. \& Watt, D. (2013). English accents and dialects: An introduction to social and regional varieties of English in the British Isles. Routledge.

Jackson, H., \& Amvela, E. Z. (2007). Words, meaning and vocabulary. A \& C Black Publishers Limited.

Leith, M. D., \& Leith, D. (2005). A social history of English. Routledge.

Levine. I. (1971). English Composition and Language. Boston: Ginn and Company. 
Mencken, H. L. (1948-73). The American Language: An Inquiry into the Development of English in the United States. 2 V. Set. AA Knopf, p. 426.

Qiong, H. X. (2004). Why China English should stand alongside British, American, and the other "world Englishes". English Today, 20(2), 26-33.

Webster. (1961). Third New International Dictionary of the English Language (Vol. 1). Chicago: Encyclopedia Britannica.

\section{Copyrights}

Copyright for this article is retained by the author, with first publication rights granted to the journal.

This is an open-access article distributed under the terms and conditions of the Creative Commons Attribution license (http://creativecommons.org/licenses/by/4.0/). 